\title{
Fluorescein Isothiocyanates: Improved Synthesis and Purity
}

\section{Spectral Studies ${ }^{1}$}

\author{
JOSEPH E. SINSHEIMER, VJEKOSLAY JAGOICI," AXI \\ JONEPH H. BLRCKIIAITER \\ College of Pharmacy, The Unieswily of Michingen. \\ Ann Arbor, Michigan strí
}

Rowived April 25, 1973: aceopted July 6. 1973

\begin{abstract}
Modifiation of the methods of synthesis by direre resution of the isomerie aminofluoreserins with a limited excess of thiophosgene in the fresenee of aleium carbonate has yielded the 5- and 6-isothioeyanatofluoresceins of high purity. The ir and nume speretria of these isomers are dexcribed.
\end{abstract}

Fluorescein isothiocyanate has been widely used as a fluoresent labeling agent 11 ) since its introduction in 1958 (2). This reagent was areepted without complete establishment of structure or stamdares of purity.

The methor of synthesis of the isothiocyanate was modified from the procedure (3) for the isocyanate which employed the isomeric 5-and 6nitrofluoresceins ats key intermediates. While these isomers hawl been readily separated on the basis of differential solubility of their acetates in aretie anhydride 13 , it was later that structures were assigned to these acetates by Corey and (hurchill (4).

Iack of purity of the fluoresecin isothiocyanates remains a problem in their optimal use in protein labeling $15-71$. Physieal and chemical methods for examining this purity have been reviewed ated applied to eommercially available samples (8). More recently, (herry et al. (9) have cxamined the purity of commercially available fluoresecin isothiocyanates hased upon their bovine serum albumin labeling effieioney. They recommend $70 \%$ minimal purity for immunofluoresein applications.

It is the purpose of this paper to deseribe a modifieation of syathesis of the fluoresecin isothiocyanate isomers which yiclds products of improved purity.

${ }^{1}$ This work was supported he IT. S. Publie Houlth Serviee researeh grant AI 05817 from the National Instiute of Alleryy and Infertious Diseases.

"Prosent address: Insitut. "Rudjer Boškovió," Ząrebl, Yugoslavia.

$22 \pi$

Copryight (c) 1974 by Academic Presa Ine.

All rights of reproduction in any form reserved. 


\section{METHODS}

Spectra. Nuclear magnetic resonance spectra were obtained with a Varian A-60A spectromoter in acetone with tetramethylsilane as the internal standard. Infrared spectra were obtained in limethylsulfoxide in silver chloride cells and as solid state spectra in potassium bromide and as Nujol or Flurolube mulls with a Perkin-Elmer model 337 spectrophotometer.

5-Isothiocyanatofuorescein. A suspension of $4.9 \mathrm{~g}$ (0.0141 mole) 5aminofluorescein (10) and $5 \mathrm{~g}(0.05$ mole) finely pulverized calcium carbonate in $150 \mathrm{ml}$ of acetone was vigorously stirred while $1.2 \mathrm{ml}(0.0161$ mole) thiophosgene was added all at once. Stirring was continued $1 \mathrm{hr}$ at room temperature and then 2 hr under reflux. The warm mixture was filtered to separate the calcium salts, and these salts were extracted and washed with boiling acetone. The combined acetone solutions were concentrated to about $60 \mathrm{ml}$, and petrolcum ether $\left(60-70^{\circ}\right)$ was added until permanent turbidity resulted. After the mixture had stood, impurities precipitated in the form of a viscous oil which was separated by filtration. More petroleum ether was added, and cooling gave $2.9 \mathrm{~g}(52.7 \%$ yicld) of orange-yellow crystals which slowly decomposed above $160^{\circ} \mathrm{C}$. After two recrstallizations from acetone-petroleum ether, an orangeyellow product was obtained which gave single spots upon silica gel tle in two systems [System I: ethyl acetate:pyridine:acetic acid (50:1:1). System II: dimethylformamide:chloroform:28\% ammonium hydroxide 110:5:4) †. Tnfrared (dimethylsulfoxide) 2110 (NCS), $1760 \mathrm{~cm}^{-1} \quad(\mathrm{C}=\mathrm{O})$; $\mathrm{nmr}$ (acetonc- $\left.\mathrm{l}_{6}\right) \delta 6.60-6.78(6 \mathrm{H}, \mathrm{m}$ with most pronounced peaks at 6.68 and 6.75 , xanthene $-\mathrm{H}), 7.35\left(1 \mathrm{H}, \mathrm{d}, J=8 \mathrm{~Hz}, \mathrm{C}_{\mathrm{i}}-\mathrm{H}\right), 7.78(1 \mathrm{H}, \mathrm{d}$ of (l, $\left.J=8, J=2 \mathrm{~Hz}, \mathrm{C}_{6}-\mathrm{H}\right), 7.93\left(1 \mathrm{H}, \mathrm{d}, J=2 \mathrm{~Hz}, \mathrm{C}_{1}-\mathrm{H}\right), 8.8 .5$ (broad s, acidic - H).

Anal. Caled for $\mathrm{C}_{2} \mathrm{H}_{11} \mathrm{NO}_{5} \mathrm{~S}: \mathrm{C}, 64.78 ; \mathrm{H}, 2.85 ; \mathrm{N}, 3.56 ; \mathrm{S}, 8.23$. Found: C, $64.85 ; \mathrm{H}, 2.96 ; \mathrm{N}, 3.54 ; \mathrm{S}, 8.27$.

6-Isothiocyanatofuorescein. This compound was synthesized from 6aminofluorescein (10) by the same procedure used for the 5 -isothiocyanate isomer. Recrystallization from acetone-petroleum ether was repeated until a single spot was obtained by tle in Systems I and II. Infrared (dimethylsulfoxide) 2110 (NCS), $1760 \mathrm{~cm}^{-1} \quad(\mathrm{C}=0)$; nmr (acetone-d $\mathrm{d}_{6}$ ) $\delta$ 6.67-6.78 $(6 \mathrm{H}$, m with most pronounced peaks at 6.70 and 6.75 , xanthene $-\mathrm{H}), 7.30\left(1 \mathrm{H}, \mathrm{d}, J=2 \mathrm{~Hz}, \mathrm{C}_{\mathrm{\tau}}-\mathrm{H}\right), 7.63(1 \mathrm{H}, \mathrm{d}$ of $\mathrm{d}, J=8$, $\left.J=2 \mathrm{~Hz}_{z} \mathrm{C}_{-}-\mathrm{H}\right), 8.05\left(1 \mathrm{H}, \mathrm{d}, J=8 \mathrm{~Hz}, \mathrm{C}_{+}-\mathrm{H}\right), 8.92$ (broad s, acidic $-\mathrm{H})$.

Anal. Found: C, $64.82 ; \mathrm{H}, 2.94 ; \mathrm{N}, 3.42 ; \mathrm{S}, 8.27$. 


\section{RESULTS AND DISCUSSION}

Our first approach to improve the purity of fluorescein isothiocyanate involyed an attempted purification of 5 -aminofluorescein diacetate, since this compound, in spite of a wirle melting range $\left(145-160^{\circ} \mathrm{Cl}\right.$, was used as an intermediate without further purification in the carlier procedure (2). It is interesting that repeated recrystallization from methanolwater of the product of the reduction of 5 -nitrofluorescein diacetate artually lauls to a docrease in purity.

Mekinney, spillane, and Parce 181 have reported that hydrogen chloride formed during reaction of aminofluoresecin with thiophosgene results in the formation of a hydrochloride of fluorescein isothiocyanate. According to these anthors, the extent of hydrochloride formation is not consistent, but, in all cases, the hydrogen chloride is extremely difficult to remove, and it is an important factor infueneing purity and stability of the intermediate. It was, therefore, concluded in the present investigation that the usual use of a large exess of thiophoxgene was to be avoided and that calcium carbonate should be added to the reaction mixture to prevent an aremumulation of hydrogen chloride.

When 5-aminofluoresein diacetate was reacter with thophosgene in this manne. 5-isothoryanatofuoresein diacetate was isolated with elemental analyis values within reasonahle agreement with theoretical values. Fince the loss of excess hyclrogen chloride also prevented the simulaneous cleavage of the ester groups which occurs in the original procedure (2), a separate hydrolysis was recuired. The undesirability of using mineral acids, owing to salt formation, resulterl in the craluation of systoms involving aqueous sodium bicalbouate and dry ammoniaacctone. Both systems not only produced rapid aleavage of the acetate groups, but they also resulted in reaction with the isothioryanato group.

In order to avoid the necessity of acetate hydrolysis, aminofluorescein instead of aminofluoreseein diacetate was used in the present procedure to obtain pure fuoresein isothioeynate. The improved promedure of Mckinney. Spillane, and Pcarce (10), which employs a mixture of sodium hydrogen sulfide and solium sulfide, was used in preference to the original Raney nickel reduetion of the 5- and 6-nitrofluoresecin isomers employed hy Coons and Kaplan (3).

Fach aminofluorescrin isomor was separately reacted with thiophosseme in acetone in the presenes of ealeium earbonate. After these reactions were completed, calcium salts wore separated by filtration, and since the atcium salts rontained considerable product, they were extracted repeatedly with hot acetone. The fluorescein isothioeyanate isomers were 
recovered from combined filtrates and extracts by evaporation of the acetone. Purification of residues was carricd out by recrystallization from acctone-pe.roleum cther. The initial addition of petroleum either precipitated impurities in the form of a viscous oil, while further addition of petroleum ether produced yellow-orange crystals. Repeated recrystallizations from acetone-petroleum ether of each of the 5- and 6-isothiocyanatofluorescein isomers produced products of high purity. Single spots were observed upon silica gel tlc in two systems, and elemental analyses consistent with the theoretical values were obtained.

Nuclear magnetic resonance spectra were obtained from saturated solutions in acctone- $\mathrm{d}_{f i}$. While there was increased solubility in dimethysulfoxide- $d_{i}$, such solutions lack stability and were sensitive to the addition of traces of dry $\mathrm{HCl}$.

In agreement with the previously published assignments for the nitrofluorescein acetates (4), the NMR spectrum of isomer I is consistent with the 5-isothiocyanato compound (A), while isomer II corrosponds to the 6-isothiocyanato compound (B). These assignments for isomers I and II are also in agreement, with the isomer assignments reached by Kramer, Klapper, and Miller (11), but our assignments do not agrce with thcir NMR spectra for 5-isothiocyanatofluorescein. It would appear that these

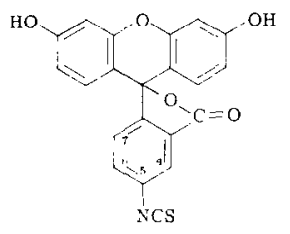

A (isomer I)

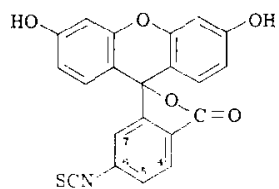

B (isomer II)

authors have inadvertently reported the spectra of isomer II for that of isomer I.

The ir spectra of these isomers, and especially isomer I, are unusually sensitive to the media in which they are obtained. Both isomers exhibit absorption at $2110 \mathrm{~cm}^{-1}$ for the isothiocyanato group and at $1760 \mathrm{~cm}^{-1}$ for the carbonyl group when determined in dimethylsulfoxide (12). The solid-state ir spectra for the 5-isothiocyanatofluorescein isomer indicates the existence of both a yellow and red form of the compound analogous to those described for fluorescein per se (13). The yellow form has isothiocyanato absorption at $2030 \mathrm{~cm}^{-1}$, but it exhibited no carbonyl bond when the compound was reduced in particle size in a mortar already moistened with mulling agent (Nujol or Flurolube). However, when ground in a dry mortar before the addition of mulling agent, the compound reddened in color and the resulting spectra had broad isothio- 
cyanato absorption at $2030 \mathrm{~cm}^{1}$ with a shoulder at $2070 \mathrm{~cm}{ }^{1}$, as well as carbonyl absorption at $1740 \mathrm{~cm}^{-1}$ with a shoulder at $1760 \mathrm{~cm}^{ }$. In $\mathrm{KBr}$, the isothiocyanato band was at $2050 \mathrm{~cm}^{-1}$ and a carbonyl band at $1730 \mathrm{~cm}^{-1}$. 6-Isothiocyanatofiuoreserein was more uniform in its soliclstate spectra, with the major isothioeranato band at $2040 \mathrm{em}^{\mathrm{t}}$ and carbonyl absorption at $1740 \mathrm{~cm}^{-1}$.

\section{REFERTNCWN}

1. Nimx, R. (. (1964) Fluoreserent Protrin Tracing, 2nd ed., Willinms and Wilkins Co.. Baltinore. MD.

2. Burckthater, J. H., and Seiwatd, R. J. (1960) U. S. Patent 2,937, 186 ; RigGs, J. L., Setwald, R. J., Burckulater, J. H., Dowss. ('. M., and Mrtcalf, T. (i. (1958) Amer. J. Prthol. 34, 1081.

3. ('oon, A. II., and Kaplax. M. II. (1950) J. Exp. Met7. 91, 1.

4. Coney, H. S., and Churnill, F. C., II (1966) Nature (Lonton) 212, 1040.

5. Cioldetein, G.. Silzys, I. S., axp Chase. M. W. (1961) J. Exp. Med. 114, 89.

6. Pitrman. B., Hebert, (. A.. Cherry. W. B.. and Taylor. G. C. (1967) J. Immunol. 98, 1196.

7. Heblet, (1. A.. Pittman, B.. ani Cherry, W. B. (1967) J. Imminol. 98, 1204.

8. Mekingey, R. M., Spilane, J. T., and Pearce, G. W. (1964) Amol. Biochem. 7,74

9. Cherry, W. B.. Mchinney. R. M., Fmmel, V. M.. Spildane, J. T.. Hebert, G. A., ani Pittmax, B. (1969) Stain T'echnol. 44, 179.

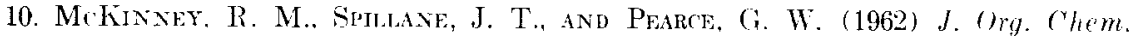
27,3986 .

11. Kramer, D., Klapper. H., axi Millier, F. (1968) Spectr. Lell. 1, 23.

12. Mrhinsey, R. M., Chimchili, F. C., II. Spllane. J. T., and Pearce, G. W. (1969) Anal. Biochem. 29, 526.

13. Sklyar, Y. E., and Mikmainov, G. I. (1966) I. Org. Chem. LisR 2, 894. 